\title{
Selective modulation of protein C affinity for EPCR and phospholipids by Gla domain mutation
}

\author{
Roger J. S. Preston ${ }^{1}$, Ana Villegas-Mendez ${ }^{1}$, Yong-Hui Sun ${ }^{2}$, José Hermida ${ }^{1, *}$, Paolo Simioni ${ }^{3}$, \\ Helen Philippou ${ }^{1} \uparrow$, Björn Dahlbäck ${ }^{2}$ and David A. Lane ${ }^{1}$ \\ 1 Department of Haematology, Division of Investigative Science, Hammersmith Campus, Imperial College London, UK \\ 2 Department of Laboratory Medicine, Division of Clinical Chemistry, Lund University, University Hospital, Malmo, Sweden \\ 3 Department of Medical and Surgical Sciences, 2nd Chair of Internal Medicine, University of Padua Medical School, Italy
}

\section{Keywords}

protein $\mathrm{C}$; activated protein $\mathrm{C}$, endothelial cell protein $\mathrm{C}$ receptor

\section{Correspondence}

D. A. Lane, Department of Haematology, Imperial College London, Hammersmith Hospital Campus, London W12 ONN, UK E-mail: d.lane@imperial.ac.uk

\section{* Present address \\ Department of Haematology, University of Navarra, Pamplona, Spain \\ tPresent address \\ Academic Unit of Molecular Vascular Medi- cine, University of Leeds School of Medi- cine, UK}

(Received 9 July 2004, revised 6 September 2004, accepted 9 September 2004)

doi:10.1111/j.1432-1033.2004.04401.x
Uniquely amongst vitamin $\mathrm{K}$-dependent coagulation proteins, protein $\mathrm{C}$ interacts via its Gla domain both with a receptor, the endothelial cell protein $\mathrm{C}$ receptor (EPCR), and with phospholipids. We have studied naturally occurring and recombinant protein $\mathrm{C}$ Gla domain variants for soluble (s)EPCR binding, cell surface activation to activated protein $\mathrm{C}$ (APC) by the thrombin-thrombomodulin complex, and phospholipid dependent factor $\mathrm{Va}$ (FVa) inactivation by APC, to establish if these functions are concordant. Wild-type protein $\mathrm{C}$ binding to sEPCR was characterized with surface plasmon resonance to have an association rate constant of $5.23 \times 10^{5} \mathrm{M}^{-1} \cdot \mathrm{s}^{-1}$, a dissociation rate constant of $7.61 \times 10^{-2} \mathrm{~s}^{-1}$ and equilibrium binding constant $\left(K_{\mathrm{D}}\right)$ of $147 \mathrm{~nm}$. It was activated by thrombin over endothelial cells with a $K_{\mathrm{m}}$ of $213 \mathrm{~nm}$ and once activated to APC, rapidly inactivated FVa. Each of these interactions was dramatically reduced for variants causing gross Gla domain misfolding (R-1L, R-1C, E16D and E26K). Recombinant variants Q32A, V34A and D35A had essentially normal functions. However, R9H and H10Q/S11G/S12N/D23S/Q32E/N33D/H44Y (QGNSEDY) variants had slightly reduced $(<$ twofold) binding to $\mathrm{SEPCR}$, arising from an increased rate of dissociation, and increased $K_{\mathrm{m}}$ (358 $\mathrm{nm}$ for QGNSEDY) for endothelial cell surface activation by thrombin. Interestingly, these variants had greatly reduced (R9H) or greatly enhanced (QGNSEDY) ability to inactivate FVa. Therefore, protein $\mathrm{C}$ binding to sEPCR and phospholipids is broadly dependent on correct Gla domain folding, but can be selectively influenced by judicious mutation.
The protein $\mathrm{C}$ anticoagulant pathway is essential for normal haemostasis, downregulating thrombin generation after the coagulation cascade has been activated $[1,2]$. When thrombin binds to the endothelial cell transmembrane protein thrombomodulin, its potent procoagulant functions are reversed, and its substrate specificity is redirected towards protein $\mathrm{C}$, which it activates. This key step is enhanced by a second endothelial cell transmembrane protein, the endothelial cell protein $\mathrm{C}$ receptor (EPCR) [3-5], which concentrates protein $\mathrm{C}$ on the endothelial cell surface, reducing the $K_{\mathrm{m}}$ for protein $\mathrm{C}$ activation by the thrombin-thrombomodulin complex [6]. Activated protein C (APC) exerts its anticoagulant activity by inactivating factors $\mathrm{Va}$ (FVa) and VIIIa by limited proteolysis, thereby attenuating thrombin generation [7-9]. APC-mediated inactivation of $\mathrm{FVa}$ involves the cleavage of peptide bonds at positions Arg306, Arg506 and Arg679 of FVa

\section{Abbreviations}

APC, activated protein C; FVa, factor Va; SEPCR, soluble endothelial cell protein C receptor; SPR, surface plasmon resonance. 
[10,11]. Cleavage at Arg506 occurs approximately 20fold faster than cleavage at Arg306 [12], and this step is greatly accelerated by the presence of anionic phospholipids [13]. The cleavage at Arg679 (the slowest of the three cleavage steps) is of uncertain functional significance, but may contribute to the inactivation of two naturally occurring FV variants, FV Cambridge and FV Hong Kong [14]. APC also activates proteaseactivated receptor 1 (PAR1) [15], and has been shown to protect brain endothelial cells from p53-mediated apoptosis in an EPCR-dependent manner [16].

Cell surface full-length EPCR (residues 1-221, mature protein numbering) and truncated EPCR (soluble or sEPCR, residues 1-193) bind protein C and APC with equal affinity [17-19]. The interaction of protein $\mathrm{C}$ with EPCR/sEPCR is dependent upon $\mathrm{Ca}^{2+}$ ions $[3,18]$. The Gla domain of protein $\mathrm{C}$, through which the interaction with EPCR takes place, is the source of this $\mathrm{Ca}^{2+}$ dependence [20]. The Gla domain contains post-translationally $\gamma$-carboxylated Glu residues and undergoes a large structural transition in the presence of physiological concentrations of $\mathrm{Ca}^{2+}$ ions [21-23]. A critical step in the structural transition is the formation of the $\omega$-loop (approximately residues 1-11) $[24,25]$. This endows protein $C$, and other vitamin K-dependent proteins, with the ability to bind anionic phospholipid surfaces $[16,26,27]$ and is therefore crucial for its activity.

The crystal structures of recombinant sEPCR, and sEPCR in complex with the Gla domain of protein C, have recently been solved [25]. As predicted [18,28-30], the overall fold of sEPCR is similar to that of the $\mathrm{CD} 1 / \mathrm{MHC}$ class I family of proteins, consisting of a $\beta$-pleated sheet platform supporting two $\alpha$-helices. A tightly bound phospholipid moiety was found to reside in the groove between the two $\alpha$-helices of the EPCR. Although it does not seem to interact with protein $\mathrm{C}$ directly, the phospholipid moiety appears to be required for protein C binding to EPCR [25]. A small clustered patch of residues on the EPCR, which include residues on both $\alpha$-helices, was found to interact with protein $\mathrm{C}$ [31]. These residues were positioned to interact with the Gla domain of protein $\mathrm{C}$, specifically the $\omega$-loop.

Information on the functional consequences of residue substitution in the protein $\mathrm{C}$ Gla domain has come from two sources. Firstly, protein $\mathrm{C}$ deficiency is a known risk factor for venous thrombosis and the mutational analysis of this deficiency has identified causative amino acid substitutions [32]. Type II (functional) deficiency is associated with normal protein $\mathrm{C}$ antigen levels but reduced activity. Type II clotting deficiency is diagnosed when the amidolytic activity with respect to synthetic substrates is normal, but the anticoagulant activity is reduced. In the latest published update of the protein $\mathrm{C}$ deficiency database, of the 335 mutations (161 unique events) that have been identified in patients in association with protein $\mathrm{C}$ deficiency, at least 30 are associated with type II clotting deficiency and 14 of these are located in the Gla domain [32]. Secondly, more detailed structure-function relationships have been identified by in vitro mutagenesis and expression of recombinant protein $\mathrm{C}$ variants. Using this approach, loss- and gain-of-function variants have been characterized [33-39].

Most investigations of the functional properties of protein C Gla domain variants have focused upon APC interaction with anionic phospholipids and the subsequent effect on FVa inactivation; that is the anticoagulant function of the enzyme. Before this anticoagulant function can be expressed, however, protein $\mathrm{C}$ must first be activated on the endothelial cell surface. Activation involves protein $\mathrm{C}$ interaction with EPCR and presentation of EPCR-bound protein C to the thrombin-thrombomodulin complex for proteolysis of its activation peptide. In this report, we examine how binding to EPCR is influenced by protein C Gla domain mutation, with particular reference to naturally occurring protein $\mathrm{C}$ Gla domain variants associated with type II clotting deficiency. We also provide the first evidence that the EPCR and membrane binding properties of protein $\mathrm{C}$ can be selectively influenced by specific mutation.

\section{Results}

\section{Expression and characterization of recombinant EPCR}

Recombinant wild-type sEPCR was prepared using the yeast Pichia pastoris expression system. In addition to binding protein $\mathrm{C}$ with expected affinity (see below), the wild-type sEPCR was also able to inhibit the anticoagulant activity of APC in a modified clotting assay, as described previously [40]. Using SDS/PAGE and Western blot analysis with the rat monoclonal RCR-2, sEPCR was found to be heterogeneous, probably due to N-linked glycosylation. Indeed, treatment of sEPCR with PNGase F resulted in increased mobility and the smeared bands resolved into a single defined band (data not shown). Variant forms of sEPCR were generated by site-directed mutagenesis (N30Q, L37A and E86A) and were expressed, concentrated and bufferexchanged using gel filtration. These mutants migrated with similar mobility to that of wild-type sEPCR on SDS/PAGE, except for variant N30Q that had slightly 
increased mobility attributed to the removal of a predicted carbohydrate side chain.

\section{Expression and characterization of protein C Gla domain variants}

Two natural protein $\mathrm{C}$ variants, $\mathrm{R}-1 \mathrm{~L}$ and $\mathrm{R}-1 \mathrm{C}$, were selected for study and the variant component isolated from plasma. Two other naturally occurring protein $\mathrm{C}$ variants, R9H and E26K, were expressed using HEK 293 cells. Protein C variants with point mutations (E16D, Q32A, V34A and D35A) were also generated. Finally, a variant with multiple residue substitutions, H10Q/S11G/S12N/D23S/Q32E/N33D/H44Y (QGNSEDY), reported previously to exhibit enhanced anionic phospholipid affinity and increased anticoagulant activity [37], was also studied. Recombinant variants were expressed at concentrations ranging between 0.9 and $7 \mu \mathrm{g} \cdot \mathrm{mL}^{-1}$ and migrated as closely spaced $62 \mathrm{kDa}$ doublets under nonreducing conditions (data not shown), in accordance with previous reports $[36,37,41,42]$. Expressed protein $\mathrm{C}$ was subsequently concentrated and partially/fully purified from conditioned medium by ion-exchange chromatography. To ensure that the catalytic site of each variant was functional, they were activated by the human protein $\mathrm{C}$ carrier, Protac, and their amidolytic properties evaluated. The wild-type and variant preparations could all be fully activated by Protac and efficiently cleaved the chromogenic substrate $\mathrm{S}-2366$, with $K_{\mathrm{m}}$ and $k_{\text {cat }}$ parameters comparable to those for wild-type APC described in the literature [43] (data not shown).

\section{Activation of protein C Gla domain variants on the surface of endothelial cells}

To investigate the activation of protein $\mathrm{C}$ variants by the thrombin-thrombomodulin complex in the presence of EPCR, each variant was activated by thrombin over the surface of an endothelial cell line, EA.hy926. The activation of recombinant wild-type protein $\mathrm{C}$ was characterized by a $K_{\mathrm{m}}$ of $213 \pm 42 \mathrm{~nm}$ (Fig. 1 and Table 1), similar to the $K_{\mathrm{m}}$ for plasma protein C activation (155 nM; data not shown) and similar to previously reported values [4].

The activation of variants E16D and E26K by thrombin on EA.hy926 cells at concentrations up to $1 \mu \mathrm{M}$ was barely detectable (Fig. 1A and Table 1). However, small amounts of protein $\mathrm{C}$ could be activated on the surface of endothelial cells at concentrations higher than $1 \mu \mathrm{M}$, suggesting some activation by the thrombin-thrombomodulin complex had taken place (data not shown).
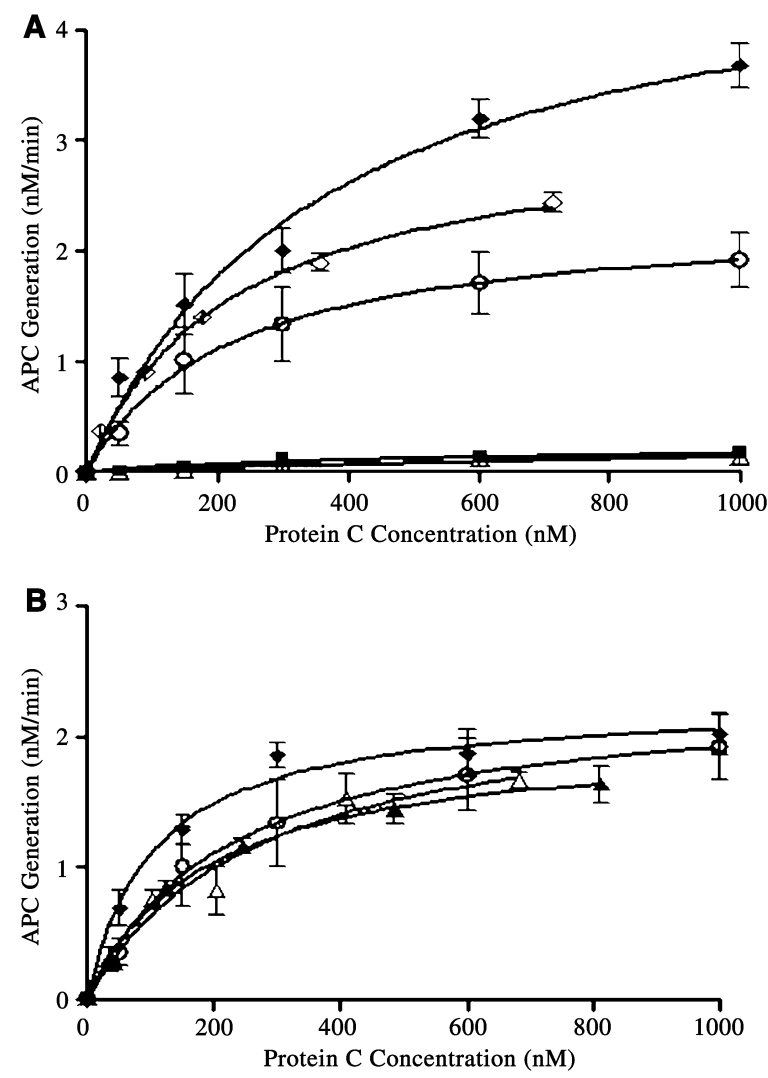

Fig. 1. Activation of protein C Gla domain variants on EA.hy926 cells. EA.hy926 cells were grown in triplicate to confluence in the wells of a 96-well plate and washed as described in Experimental procedures. Recombinant protein $\mathrm{C}$ was added to the wells in a range of concentrations (12.5-1000 nM) in HBSS containing $3 \mathrm{~mm}$ $\mathrm{CaCl}_{2}$ and $0.6 \mathrm{mM} \mathrm{MgCl}$ and activation initiated by the addition of $13.5 \mathrm{~nm}$ thrombin. After $30 \mathrm{~min}$, the thrombin was inhibited with a 10-fold excess of hirudin (135 nM) and the APC formed detected with the chromogenic substrate S-2366 (see text). (A) Protein C variants $\mathrm{R} 9 \mathrm{H}(\diamond) ; \operatorname{E16D}(\triangle)$; $\operatorname{E26K}(\mathbf{\square})$; QGNSEDY $(\diamond)$. (B) Q32A $(\mathbf{\Delta})$; V34A $(\triangle)$; D35A $(\diamond)$. Wild-type protein $C(O)$ in both panels. Results are presented as the mean \pm SD of three individual experiments.

The $K_{\mathrm{m}}$ values for activation of variants $\mathrm{R} 9 \mathrm{H}$, Q32A, V34A, D35A and QGNSEDY on the cell surface were normal or slightly increased (Fig. 1 and Table 1). Activation of QGNSEDY and R9H variants was also characterized by slight increases in the $V_{\max }$ for this reaction, with the increase for QGNSEDY being approximately twofold (Fig. 1A, Table 1). To further investigate this, the activation of QGNSEDY by thrombin on the surface of cells expressing thrombomodulin alone was determined. Interestingly, over the surface of HEK293-TM cells, the $K_{\mathrm{m}}$ for activation of wild-type protein C and QGNSEDY by thrombin were closely comparable $\left(K_{\mathrm{m}}=666 \pm 182 \mathrm{nM}\right.$ and 
Table 1. Activation of protein C Gla domain variants on EA.hy926 cells. $K_{m}$ values were derived by fitting data derived from the activation of protein $C$ on the surface of EA.hy 926 cells with thrombin (Fig. 1) to the Michaelis-Menten equation. $K_{\mathrm{m}}$ values were obtained for each variant, and represent the mean \pm SD of a minimum of three independent experiments, except R-1L and R-1C, where $n=2$ due to limited material isolated from plasma. ND, not detectable.

\begin{tabular}{lll}
\hline Protein C & $K_{\mathrm{m}}(\mathrm{nm})$ & $V_{\max }\left(\mathrm{nm} \cdot \mathrm{min}^{-1}\right)$ \\
\hline Wildtype protein C & $213 \pm 42$ & $2.35 \pm 0.16$ \\
R-1C & $\mathrm{ND}$ & $\mathrm{ND}$ \\
R-1L & $\mathrm{ND}$ & $\mathrm{ND}$ \\
R9H & $224 \pm 18$ & $3.15 \pm 0.10$ \\
E16D & $\mathrm{ND}$ & $\mathrm{ND}$ \\
E26K & $\mathrm{ND}$ & $\mathrm{ND}$ \\
Q32A & $188 \pm 28$ & $2.03 \pm 0.18$ \\
V34A & $236 \pm 80$ & $2.37 \pm 0.08$ \\
D35A & $123 \pm 8$ & $2.27 \pm 0.09$ \\
QGNSEDY & $358 \pm 76$ & $4.99 \pm 0.34$ \\
\hline
\end{tabular}

$603 \pm 112 \mathrm{nM}, n=3$ ), respectively, with no difference in $V_{\max }$. This indicated that the increased $V_{\max }$ was dependent upon cell-surface EPCR.

\section{Affinity of protein C Gla domain variants for sEPCR}

Surface plasmon resonance (SPR) was used to analyse the binding kinetics of each protein $\mathrm{C}$ variant for sEPCR. sEPCR has been previously reported to lose activity when bound directly to artificial surfaces [4]. Therefore, the anti-EPCR monoclonal antibody, RCR2, was first immobilized onto the surface of a CM5 sensor chip, and sEPCR captured onto one of the two flow cells of the sensor chip. To investigate the nature of RCR-2 binding to sEPCR, recombinant wild-type sEP$\mathrm{CR}$ and several sEPCR variants were expressed and their concentrations and binding to RCR-2 determined by SPR. Wild-type sEPCR bound to RCR-2 with an association rate, $k_{\mathrm{a}}$, of $5.39 \pm 0.97 \times 10^{4} \mathrm{M}^{-1} \cdot \mathrm{s}^{-1}$ and dissociated with a $k_{\mathrm{d}}$ of $3.28 \pm 0.58 \times 10^{-4} \cdot \mathrm{s}^{-1}$. The equilibrium constant $\left(K_{\mathrm{D}}\right)$ was $6.1 \pm 0.1 \mathrm{nM}$ (Fig. $2 \mathrm{~A}$ and Table 2). Similar results were obtained with variant sEPCR with the substitution E86A. Glu86 is an important residue of the protein $\mathrm{C}$ binding site on EPCR [25,31]. In contrast, sEPCR with substitutions N30Q and L37A had an impaired interaction, with the $k_{\mathrm{d}}$ for $\mathrm{N} 30 \mathrm{Q}$ being particularly increased $(\approx$ fourfold) to $1.15 \pm 0.04 \times 10^{-3} \mathrm{~s}^{-1}$ (Fig. 2B and Table 2). The $K_{\mathrm{D}}$ for this variant was also increased to $16.3 \pm 1.4 \mathrm{~nm}$. These results demonstrate a slow off rate $\left(k_{\mathrm{d}}\right)$ for the interaction between wild-type sEPCR and RCR-2 and furthermore suggest that the epitope for RCR-2 on sEPCR is on the face of sEPCR opposite to its known binding site for protein $\mathrm{C}$. The stability of immobilized RCR-2 as a capture ligand for sEPCR and protein $\mathrm{C}$ is illustrated in Fig. 2C. This shows initial binding of sEPCR to RCR-2 (Fig. 2C; panel 1), the addition of increasing concentrations of protein $\mathrm{C}-$ showing association, dissociation and regeneration experiments - (Fig. 2C; panel 2) and final regeneration of the RCR-2 immobilized chip by injection of $10 \mathrm{~mm}$ glycine/ $\mathrm{HCl}$ (Fig. 2C; panel 3).

The binding of protein $\mathrm{C}$ to sEPCR was initially characterized using wild-type and variant forms of sEPCR. Human plasma protein C associated with RCR-2 immobilized wild-type sEPCR in a concentrationdependent manner (Fig. 3A). The association and dissociation rate constants were $12.1 \pm 1.29 \times 10^{5} \mathrm{M}^{-1} \cdot \mathrm{s}^{-1}$ and $8.96 \pm 1.09 \times 10^{-2} \mathrm{~s}^{-1}$, yielding a calculated $K_{\mathrm{D}}$ of $74.8 \pm 9.2 \mathrm{~nm}$. Binding of plasma protein $\mathrm{C}$ was completely abolished when sEPCR with the substitution E86A was used (Fig. 3B).

Recombinant wild-type protein $\mathrm{C}$ bound to sEPCR with a $K_{\mathrm{D}}=147 \pm 23 \mathrm{~nm}$ (Table 3 ), somewhat higher than the value derived for plasma protein $\mathrm{C}$. This was caused by a lower $k_{\mathrm{a}}$ for recombinant protein $\mathrm{C}$ $\left(5.23 \pm 0.74 \times 10^{5} \mathrm{M}^{-1} \cdot \mathrm{s}^{-1}\right)$ (Table 3) compared with plasma protein $\mathrm{C}\left(12.1 \pm 1.29 \times 10^{5} \mathrm{M}^{-1} \cdot \mathrm{s}^{-1}\right)$. The two protein $\mathrm{C}$ Gla domain variants sourced from human plasma, those containing R-1C and R-1L substitutions, exhibited no binding to sEPCR (Table 3). Also, no detectable binding for variants E16D and E26K to sEPCR was observed at concentrations up to $200 \mathrm{nM}$ (Table 3). Protein C variants R9H, Q32A, V34A, D35A, and QGNSEDY variants had readily detectable binding to sEPCR, but all exhibited slightly reduced affinities compared to recombinant wild-type protein $\mathrm{C}$ (Table 3). Repeated analyses also suggested slightly faster dissociation rates (approximately twofold) for the R9H and QGNSEDY variants compared to recombinant wild-type protein $\mathrm{C}$, which may have contributed to the increased $K_{\mathrm{D}}$ values of $256 \pm 96$ and $216 \pm 53 \mathrm{~nm}$, respectively (Table 3 ).

\section{Inactivation of FVa by APC Gla domain variants}

The inactivation of FVa on phospholipids by APC is strongly dependent on APC binding to anionic phospholipids. Therefore, to indirectly assess APC variant affinity for phospholipids, FVa inactivation by each recombinant variant was determined. FVa inactivation by recombinant wild-type APC was characteristically biphasic, with rate constants of $4.63 \times 10^{7} \mathrm{M}^{-1} \cdot \mathrm{s}^{-1}$ and $5.51 \times 10^{6} \mathrm{M}^{-1} \cdot \mathrm{s}^{-1}$ for cleavage of FVa at Arg506 and Arg306, respectively, in agreement with previously 
A

RU
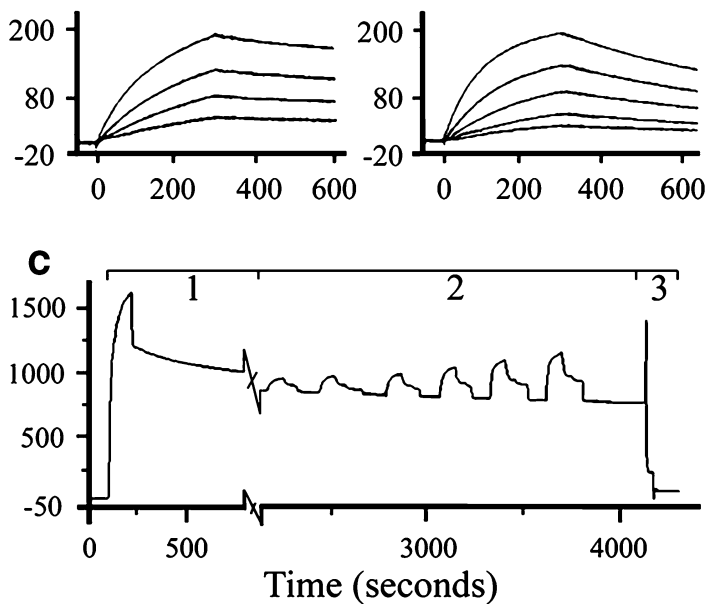

Fig. 2. SPR analysis of binding between sEPCR and protein $C$ using the capture mAb RCR-2. (A) Binding of wild-type sEPCR to RCR-2. Approximately $200 \mathrm{ng}$ mAb RCR-2 was immobilized on one flow cell of a CM5 sensor chip, giving a corrected response of $2000 \mathrm{RU}$ (see Experimental procedures). A nonreactive mAb was used as a control for nonspecific binding in the reference flow cell. Increasing concentrations of wild-type SEPCR (13-106 nM) were injected across both flow cells. The association of sEPCR with RCR-2 was assessed for $5 \mathrm{~min}$ at a flow rate of $20 \mu \mathrm{L} \cdot \mathrm{min}^{-1}$. (B) Binding of sEPCR N300 to RCR-2. The amount of immobilized RCR-2 corresponded to $1500 \mathrm{RU}$. The experiment was otherwise performed under identical conditions to A using SEPCR variant N30O instead of wild-type sEPCR (concentration range 7.2-115 nM). (C) Complete EPCR/protein C binding cycle. 1, Wildtype sEPCR (800 ng) was injected across the flow cell of a CM5 sensor chip coated with RCR-2. sEPCR was injected for $2 \mathrm{~min}$ at a flow rate of $10 \mu \mathrm{L} \cdot \mathrm{min}^{-1}$ and equilibrated for $10 \mathrm{~min}$. 2, Increasing concentrations of plasma protein C (18-133 nM) were injected across the RCR-2-sEPCR complex, for $80 \mathrm{~s}$ at $30 \mu \mathrm{L} \cdot \mathrm{min}^{-1}$. Dissociation of protein $\mathrm{C}$ from SEPCR was achieved by injection of HBS-EP buffer, containing $3 \mathrm{mM}$ EDTA. 3, Injection of $10 \mathrm{mM}$ glycine $/ \mathrm{HCl} \mathrm{pH} 2.5$ regenerated the antibody surface by the complete removal of SEPCR from the CM5 chip surface. The data shown in the figure are representative sensograms for each set of experiments.

defined values $[12,44]$. The fitted inactivation data (Fig. 4B) and the kinetic rate constants for FVa inactivation by Q32A, V34A and D35A APC variants were virtually identical to those described for wild-type APC (data not shown). Under our experimental conditions, the severely reduced rates of FVa inactivation by R9H, E16D and E26K APC variants (Fig. 4A) meant that accurate kinetic rate constants for individual FVa cleavages using the biphasic model could not be derived. As such information was of limited value in view of the severely reduced extent of total inactivation (Fig. 4A) it was not pursued further. In contrast,
Table 2. Kinetic parameters of the binding of SEPCR and its variants to the monoclonal antibody RCR-2. Interaction of wildtype and variant SEPCR with substitution mutations N300, L37A and E86A with mAb RCR-2 as assessed by SPR (see Fig. 2). The association rate constants $\left(k_{\mathrm{a}}\right)$, dissociation rate constants $\left(k_{\mathrm{d}}\right)$ and the equilibrium dissociation constants $\left(K_{\mathrm{D}}=k_{\mathrm{d}} / k_{\mathrm{a}}\right)$ were derived from the SPR data using Biacore software (BIAEVALUATION 3.0). Data sets were fit to the 1:1 Langmuir model (see Experimental procedures). Rate constants are presented as the mean value of ( $n=2-$ 4) independent experiments \pm SD.

\begin{tabular}{lllr}
\hline $\begin{array}{l}\text { sEPCR } \\
\text { ligand }\end{array}$ & $k_{\mathrm{a}}\left(\mathrm{M}^{-1} \cdot \mathrm{s}^{-1}\right)$ & \multicolumn{1}{l}{$k_{\mathrm{d}}\left(\mathrm{s}^{-1}\right)$} & \multicolumn{1}{c}{$K_{\mathrm{D}}(\mathrm{nM})$} \\
\hline Wildtype & $(5.39 \pm 0.97) \times 10^{4}$ & $(3.28 \pm 0.58) \times 10^{-4}$ & $6.1 \pm 0.1$ \\
N300 & $(7.04 \pm 0.37) \times 10^{4}$ & $(1.15 \pm 0.04) \times 10^{-3}$ & $16.3 \pm 1.4$ \\
L37A & $(7.78 \pm 0.26) \times 10^{4}$ & $(6.45 \pm 0.78) \times 10^{-4}$ & $8.3 \pm 0.4$ \\
E86A & $(6.32 \pm 0.83) \times 10^{4}$ & $(3.51 \pm 0.20) \times 10^{-4}$ & $5.6 \pm 0.3$ \\
\hline
\end{tabular}
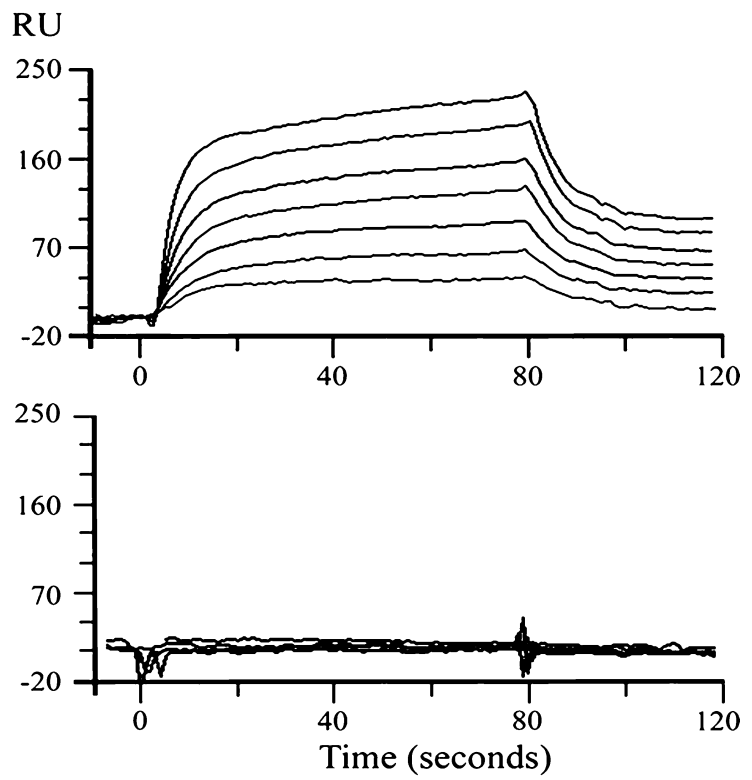

Fig. 3. Interaction of plasma protein $C$ with $s E P C R$. RCR-2 was used to capture SEPCR on a CM5 sensor chip (see Experimental procedures for details). RCR-2 (300 ng) was injected onto the sensor surface and gave a response of $3600 \mathrm{RU}$. (Upper) Binding of protein C to wild-type sEPCR. Approximately $400 \mathrm{RU}$ of sEPCR was captured before sequential injections containing decreasing concentrations of protein C (concentration range 18-200 nM). (Lower) Lack of protein C binding sEPCR with substitution E86A. The response level of this variant was $540 \mathrm{RU}$ prior to sequential injections containing decreasing concentrations of protein $\mathrm{C}$ (range 54-300 nм).

the activated QGNSEDY variant demonstrated a markedly increased ability to inactivate FVa compared to wild-type APC (Fig. 4A), with the Arg306 cleavage being mainly (2.53-fold) affected. 
Table 3. Interaction of protein C Gla domain variants with recombinant wildtype sEPCR. Affinity of protein C Gla domain variants for sEPCR was assessed using SPR. The association rate constants $\left(k_{a}\right)$, dissociation rate constants $\left(k_{d}\right)$ and equilibrium dissociation rate constants $\left(K_{D}\right)$ were derived as described in Experimental procedures using the $1: 1$ binding with drifting baseline model. Association and dissociation rates and equilibrium binding constants are presented as the mean of three independent experiments \pm standard deviation.

\begin{tabular}{llll}
\hline Protein C & $k_{\mathrm{a}}\left(\mathrm{M}^{-1} \cdot \mathrm{s}^{-1}\right)$ & $k_{\mathrm{d}}\left(\mathrm{s}^{-1}\right)$ & $K_{\mathrm{D}}(\mathrm{nM})$ \\
\hline $\begin{array}{c}\text { Wildtype } \\
\text { protein C }\end{array}$ & $(5.23 \pm 0.74) \times 10^{5}$ & $(7.61 \pm 0.45) \times 10^{-2}$ & $147 \pm 23$ \\
R-1C & No binding & No binding & No binding \\
R-1 L & No binding & No binding & No binding \\
R9H & $(5.40 \pm 2.96) \times 10^{5}$ & $(11.4 \pm 0.96) \times 10^{-2}$ & $256 \pm 96$ \\
E16D & No binding & No binding & No binding \\
E26K & No binding & No binding & No binding \\
Q32A & $(2.86 \pm 0.58) \times 10^{5}$ & $(9.98 \pm 0.21) \times 10^{-2}$ & $259 \pm 74$ \\
V34A & $(5.29 \pm 1.47) \times 10^{5}$ & $(9.80 \pm 1.56) \times 10^{-2}$ & $176 \pm 39$ \\
D35A & $(4.31 \pm 1.55) \times 10^{5}$ & $(8.42 \pm 0.51) \times 10^{-2}$ & $217 \pm 93$ \\
QGNSEDY & $(6.07 \pm 1.93) \times 10^{5}$ & $(12.8 \pm 0.58) \times 10^{-2}$ & $216 \pm 53$ \\
\hline
\end{tabular}

\section{Discussion}

Vitamin K-dependent proteins interact through their characteristic Gla domains with phospholipid membrane surfaces. The Gla domains exhibit appreciable amino acid sequence similarity. When $\mathrm{Ca}^{2+}$ is bound, the Gla domain folds into a conserved $\omega$-loop exposing surface-orientated hydrophobic residues that are proposed to make membrane contact [26]. The membrane binding properties of vitamin $\mathrm{K}$-dependent proteins is facilitated by the presence of phosphatidylserine. Recent analysis of the prothrombin Gla domain complexed with lysophosphatidylserine identified interactions of the serine head group with bound $\mathrm{Ca}^{2+}$ ions, Gla17 and Gla21. Extensive interactions were also detected between lysophosphatidylserine and residues of the $\omega$-loop, including Phe5, Leu6 and Gla7. Furthermore, the glycerophosphate backbone was shown to interact with a basic region of the Gla domain containing Lys3, Arg10 and Arg16 [27]. Consequently, a general model of Gla domain membrane contact has been proposed that involves both hydrophobic and ionic interactions. Such a model is compatible with experimental data showing the limited effects of targeted mutagenesis on Gla domain binding to membranes [33].

Of the coagulation proteins, protein $\mathrm{C}$ is unique in binding EPCR with high affinity. This interaction is mediated by the protein $\mathrm{C}$ Gla domain. According to a recent crystal structure [25], the majority of protein $\mathrm{C}$ residues contributing to the EPCR interaction
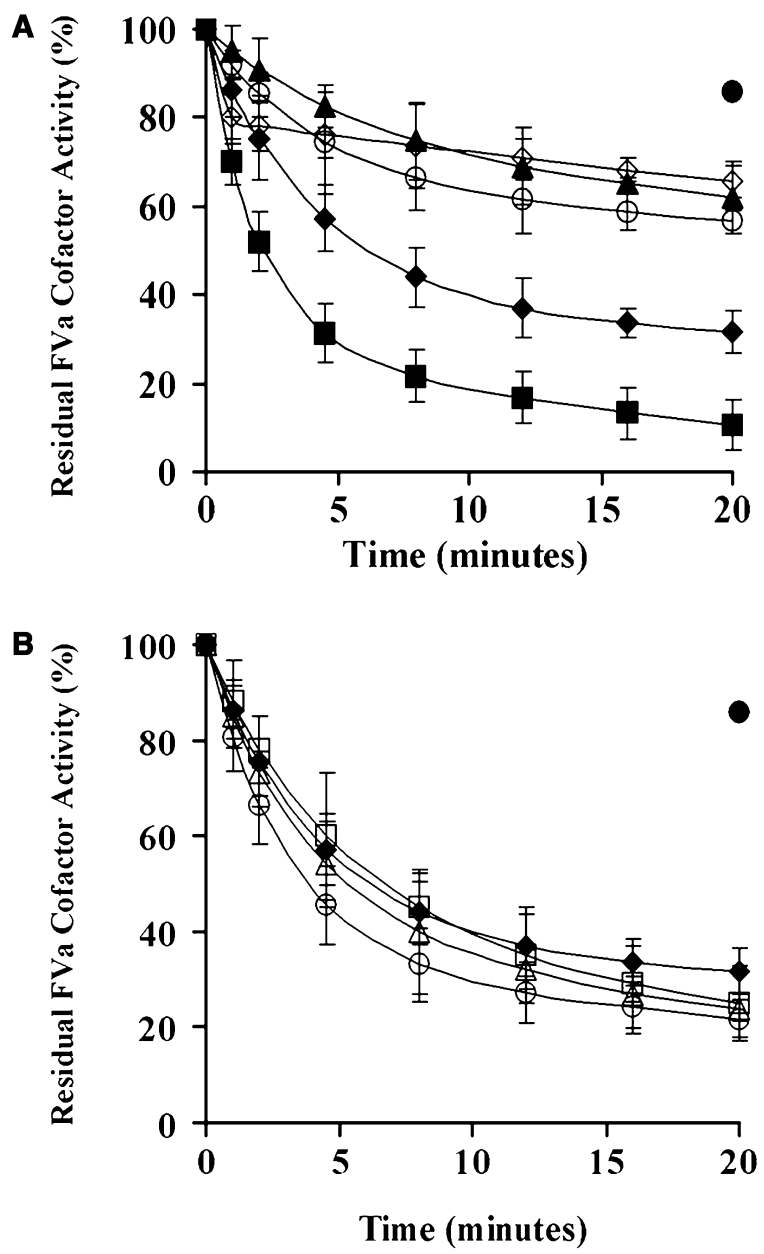

Fig. 4. Inactivation of FVa by APC Gla domain variants. FVa (4 nM) was incubated with $75 \mu \mathrm{M}$ phospholipid vesicles containing phosphatidylcholine and phosphatidylserine $(90: 10, \mathrm{v} / \mathrm{v})$ and $0.08 \mathrm{~nm}$ APC in $40 \mathrm{~mm}$ Tris $/ \mathrm{HCl}, 140 \mathrm{~mm} \mathrm{NaCl}, 3 \mathrm{~mm} \mathrm{CaCl} 2$ and $0.3 \%$ $(\mathrm{W} / \mathrm{v}) \mathrm{BSA}$ at $37^{\circ} \mathrm{C}$. Aliquots $(2 \mu \mathrm{L})$ were removed and added to $75 \mu \mathrm{M}$ phospholipids (phosphatidylcholine and phosphatidylserine; $90: 10, \mathrm{v} / \mathrm{v}), 3 \mathrm{~nm}$ factor $\mathrm{Xa}$ and $1.5 \mu \mathrm{M}$ prothrombin at time points between 0 and $20 \mathrm{~min}$. Each reaction was stopped after three minutes using $3 \mu \mathrm{L}$ ice-cold $0.5 \mathrm{M}$ EDTA. Loss of FVa activity was also determined by fitting the curves using nonlinear regression analysis (see Experimental procedures) to derive the kinetic parameters listed in [12]. (A) APC variants R9H (O); E16D ( $\triangle$ ); E26K $(\diamond)$;

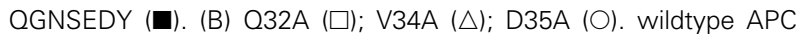
$(\bullet)$ and FVa only (-) are the same in both panels. Results are expressed as the mean \pm SD of three individual experiments.

are located on the $\omega$-loop. One direct pivotal contact was shown to be made between the $\mathrm{Ca}^{2+}$ ions bound to the protein C Gla domain and the EPCR (Glu86 of EPCR). All remaining contacts (hydrogen bonds and/or hydrophobic interactions) were directly between residues of the protein $\mathrm{C}$ Gla domain (Phe4, Gla7, Leu8, Gla25 and Gla29) and EPCR (Leu82, 
Arg87, Gln150, Tyr154 and Thr157). Consequently, the structural features of protein $\mathrm{C}$ required for membrane and EPCR interactions appear to be partially shared.

In this study, the contributions of protein C Gla domain residues to both of these interactions, and their subsequent effect on anticoagulant activity, have been examined. Nine plasma/recombinant protein $\mathrm{C}$ variants were isolated or generated, and four of these were selected because they are known to have impaired anticoagulant activity. Each of the nine variants were characterized by activation over the surface of endothelial cells, their binding to recombinant sEPCR, and by their abilities to inactivate FVa in a phospholipiddependent manner. Two of the variants $(\mathrm{R}-1 \mathrm{~L}$ and $\mathrm{R}-1 \mathrm{C}$ ) were purified from the plasma of heterozygous carriers. These variants are incorrectly processed by the signal peptidase at their amino-terminal residues. Furthermore, a proportion of the $\mathrm{R}-1 \mathrm{C}$ variant is known to be present as heterodimers with $\alpha_{1}$-microglobulin [45]. Neither variant was able to bind to sEP$\mathrm{CR}$ or be efficiently activated by thrombin over the endothelial cell surface. A further means of inhibition of the $\mathrm{Ca}^{2+}$-induced conformational change of the protein $\mathrm{C}$ Gla domain is the substitution of $\gamma$-carboxylated Glu residues. Two such substitutions arise in the naturally occurring variant E26K [46,47] and the engineered conservative substitution variant E16D. They too are shown here to be unable to bind SEPCR (Table 3), have negligible activation over the surface of endothelial cells by the thrombin-thrombomodulin complex (Table 1), and to have grossly impaired abilities to inactivate $\mathrm{FVa}$ once activated to APC (Fig. 4A).

As the natural and recombinant variants described above have such abnormal binding and activation properties, it was of interest to study other protein $\mathrm{C}$ recombinant variants in the protein $\mathrm{C}$ Gla domain that might be predicted to perturbate, but not fully disrupt, Gla domain folding and functions. Three potentially dysfunctional variants with substitutions Q32A, V34A and D35A were chosen for investigation because of a preliminary abstract report that suggested the binding site for the EPCR on protein $\mathrm{C}$ was located between residues 25 and 40 [48]. This report was based upon the observation that a chimeric molecule with residues 1-22 of prothrombin and 22-45 of protein $\mathrm{C}$ bound EPCR, whereas a protein $\mathrm{C}$ chimera with residues 145 of prothrombin did not. We therefore selected three residues on protein $\mathrm{C}$ that differed from the homologous prothrombin sequence [49] and generated variants containing an alanine residue at each of these positions. In the event, the interactions of these variants with SEPCR were essentially normal (Table 3 ), as was their activation over the endothelial cell surface (Table 1) and their ability to inactivate FVa once activated to APC (Fig. 4B).

The R9H variant, another example of a Gla domain residue substitution causing a type II deficiency phenotype [50], displayed only a small reduction in affinity for sEPCR and a similar $K_{\mathrm{m}}$ for endothelial cell activation by thrombin to that of wild-type protein $\mathrm{C}$ (Tables 1 and 3). In contrast, the ability of the R9H APC variant to fully inactivate FVa was markedly compromised (Fig. 4) suggestive of an impaired interaction with anionic phospholipids. The R9H substitution may therefore selectively perturbate protein C Gla domain function by reducing protein $\mathrm{C}$ Gla domain affinity for phospholipids without substantially affecting interaction with EPCR. The homologous residue in the bovine prothrombin Gla domain, $\operatorname{Arg} 10$ is discussed above. Our results suggest that Arg9 may form part of a similar basic region on the protein $\mathrm{C}$ Gla domain surface for contact with phosphatidylserine, and thereby contribute importantly to the protein $\mathrm{C} / \mathrm{APC}$-phospholipid interaction.

Further evidence for selective modulation of protein C Gla function is provided from results of the protein $\mathrm{C}$ variant QGNSEDY. This variant exhibited near-normal sEPCR binding (a $K_{\mathrm{D}}$ value of $216 \mathrm{~nm}$ compared to $147 \mathrm{~nm}$ for wild-type protein C; Table 3), which appears to be caused by an increased $k_{\mathrm{d}}$. The $K_{\mathrm{m}}$ and $V_{\max }$ for activation of this variant on the endothelial cell surface by the thrombin-thrombomodulin complex were slightly increased (Table 1 and Fig. 1). In contrast, the ability of QGNSEDY to inactivate FVa in a phospholipid-dependent manner was markedly enhanced (Fig. 4A), as has been reported previously [37]. Because of the composite nature of the QGNSEDY variant, it is currently uncertain how its Gla domain has been selectively altered to enhance phospholipid binding.

The results of this study highlight for the first time the importance of natural protein C Gla domain mutations in impairing protein $\mathrm{C}$ binding to EPCR and its endothelial cell surface activation by the thrombinthrombomodulin complex. Carriers of certain protein $\mathrm{C}$ Gla domain mutations are known to be at increased risk of thrombosis. It is highly plausible that impaired cell surface protein $\mathrm{C}$ activation could contribute to that risk. Protein $\mathrm{C}$ variants with gross misfolding of the Gla domain will have impaired cell surface activation that will in part be determined by a reduced interaction with EPCR. Patients with heterozygous R-1L or R-1C mutations, in particular, have been reported to present with a severe thrombotic 
manifestation. In such an instance, a deficiency of anticoagulant activity will arise from reduced APC activity against FVa due to loss of phospholipid affinity, but potentially also from an impaired rate of protein $\mathrm{C}$ activation, an inevitable by-product of deficient EPCR binding.

Recombinant APC is one of the few novel therapies to be used successfully in the treatment of sepsis [51]. Its ability to reduce mortality appears due in part to EPCR-bound APC proteolysis of PAR1 on the surface of endothelial cells [15]. PAR1 cleavage by APC has been shown to mediate signal transduction pathways and contribute to APC antiapoptotic and neuroprotective activities [16,52]. This nonanticoagulant activity is entirely reliant on the APC-EPCR interaction. Selective perturbation of protein C/APC Gla domain functions therefore represents a potential means by which the anticoagulant and nonanticoagulant functions of APC can be altered for improved therapeutic intervention in the future.

\section{Experimental procedures}

\section{Expression and purification of sEPCR}

sEPCR was expressed in Pichia pastoris strain X-33 using the EasySelect Pichia expression kit (Invitrogen, Paisley, UK) broadly as described [53]. SEPCR variants were generated using the QuikChange mutagenesis kit (Stratagene, La Jolla, CA, USA).

\section{Purification of variant protein $\mathbf{C}$ from plasma of heterozygous carriers}

The purification of variant protein $\mathrm{C}$ from the plasma of patients who were heterozygous for the mutations $\mathrm{R}-1 \mathrm{~L}$ and $\mathrm{R}-1 \mathrm{C}$ has been described previously [45,54]. Briefly, the method utilized two immunoaffinity columns directed against protein $\mathrm{C}$. The first column resulted in efficient purification of protein $\mathrm{C}$ from other plasma components, whereas the second separated normal from variant protein $\mathrm{C}$. The characterization of these APC variants has also been reported previously $[45,54]$ and consequently details of the purification and characterization will not be replicated here. The activities of these variants were compared to human plasma protein C from Enzyme Research Laboratories (ERL, South Bend, IN, USA).

\section{Vector construction and expression of recombinant protein $\mathrm{C}$}

The full-length protein C cDNA was cloned into the vector $\mathrm{pRc} / \mathrm{CMV}$ (Invitrogen, Paisley, UK) to generate wild-type protein C. Site-directed mutagenesis was performed by the Quikchange mutagenesis kit (Stratagene, La Jolla, CA, USA) to generate protein $\mathrm{C}$ variants. The oligonucleotide primers used to generate the protein $\mathrm{C}$ variant constructs R9H, E16D, E26K, Q32A, V34A and $\mathrm{D} 35 \mathrm{~A}$ are available upon request. Preparation of the H10Q/S11G/S12N/D23S/Q32E/N33D/H44Y construct has been described previously [37]. The expression of recombinant protein $\mathrm{C}$ using picked colonies of stably transfected HEK293 cells (European Collection of Cell Cultures, Wiltshire, UK) has been described in detail elsewhere [36,37]. Serum-free conditioned medium containing protein $\mathrm{C}$ was dialysed overnight against $20 \mathrm{~mm}$ Tris $/ \mathrm{HCl}$ $(\mathrm{pH} 7.4), 150 \mathrm{~mm} \mathrm{NaCl}$. Protein $\mathrm{C}$ was concentrated and partially or fully purified by ion-exchange chromatography in $20 \mathrm{~mm}$ Tris/ $\mathrm{HCl}, 150 \mathrm{~mm} \mathrm{NaCl}$ (pH 7.4), using a Q Sepharose Fast Flow column (Amersham Biosciences, Little Chalfont, UK), with either a single step elution to $1 \mathrm{M}$ $\mathrm{NaCl}$ or elution with $3 \mathrm{~mm} \mathrm{CaCl}_{2}$ [37]. Purified fractions were dialysed overnight against Hanks Balanced Salt Solution (HBSS) before use. Expressed protein $\mathrm{C}$ has been shown to have normal $\gamma$-carboxylation [37].

\section{Determination of protein $\mathbf{C}$ concentration}

Protein $\mathrm{C}$ concentrations were determined either by absorbance at $280 \mathrm{~nm}$ or by an 'in-house' ELISA. For the latter, the method was similar to that previously described for the determination of protein $\mathrm{S}$ concentration [55]. The only modifications were the antibodies used. The capture antibody was the monoclonal antibody HC-2 (directed towards the heavy chain of protein C) (Sigma-Aldrich, Poole, UK) and the detection antibody was a horseradish peroxidase (HRP)-conjugated polyclonal anti-protein C (Dako, Ely, UK). SPR was used to confirm that the affinity of each protein $\mathrm{C}$ variant for the capture antibody was identical, and unaffected by Gla domain mutation. Standards $(0.2-$ $\left.7.8 \mu \mathrm{g} \cdot \mathrm{mL}^{-1}\right)$ for the ELISA were prepared using purified plasma protein $\mathrm{C}$.

\section{SDS/PAGE and Western blotting}

SDS/PAGE and Western blotting were performed using standard techniques. Briefly, for Western blot analysis, protein $\mathrm{C}$ or sEPCR were loaded and separated by $\mathrm{SDS} / \mathrm{PAGE}$ in a $4-20 \%(\mathrm{w} / \mathrm{v})$ polyacrylamide $\mathrm{Tris} / \mathrm{HCl}$ gel (Bio-Rad, Hemel Hempstead, UK) under nonreducing or reducing conditions. Proteins in the gel were stained with GelCODE Blue stain reagent (Pierce, Rockford, IL, USA). Proteins transferred to Hybond-ECL (Amersham Biosciences) were detected using either an HRP-conjugated polyclonal anti-protein $\mathrm{C}$ or the anti-EPCR monoclonal antibody RCR-2 followed by an HRP-conjugated goat anti-(rat IgG) Ig (both from Dako). 


\section{Determination of catalytic efficiency of APC variants}

Protein $\mathrm{C}$ was activated with Protac (Immuno, Heidelberg, Germany) according to the method of Zhang and Castellino [56]. Protein $\mathrm{C}$ at $5 \mu \mathrm{g} \cdot \mathrm{mL}^{-1}$ was incubated in $50 \mathrm{~mm}$ Tris/ $\mathrm{HCl}(\mathrm{pH} 7.4), 100 \mathrm{~mm} \mathrm{NaCl}$ and $0.25 \mathrm{U}$ Protac in a total volume of $1 \mathrm{~mL}$ for $1 \mathrm{~h}$ at $37^{\circ} \mathrm{C}$ then $16 \mathrm{~h}$ at $4{ }^{\circ} \mathrm{C}$. Steady-state substrate hydrolysis by each APC variant was measured using an adapted method [57]. Essentially, $2 \mathrm{~nm}$ of each APC variant was incubated with a range of concentrations of chromogenic substrate (S-2366; Chromogenix, Milan, Italy) in $100 \mathrm{~mm} \mathrm{NaCl}, 20 \mathrm{~mm}$ Tris/ $\mathrm{HCl}$ (TBS, $\mathrm{pH} 7.5)$ containing $2.5 \mathrm{mM} \mathrm{CaCl}_{2}, 0.1 \mathrm{mg} \cdot \mathrm{mL}^{-1} \mathrm{BSA}$ and $0.1 \%(\mathrm{v} / \mathrm{v})$ polyethylene glycol (PEG 8000). The rate of S-2366 hydrolysis was measured at $405 \mathrm{~nm}$ at room temperature using an iEMS plate reader MF (Labsystems, Basingstoke, UK). Curve fitting using the MichaelisMenten equation was performed using ENZFITTER software (Biosoft, Cambridge, UK). The $K_{\mathrm{m}}$ and $k_{\text {cat }}$ values were derived from this equation.

\section{Activation of protein $c$ on endothelial cells and HEK293-TM cells}

EA.hy926 cells (the kind gift of C.-J. Edgell, University of North Carolina, Chapel Hill, NC, USA) were used as they express both EPCR [3,5] and thrombomodulin [58]. The method of protein $\mathrm{C}$ activation was a modification of that described by Suzuki et al. [59]. Cells were grown to confluence in 96-well plates and were washed using HBSS supplemented with $1 \%$ (w/v) BSA, $3 \mathrm{~mm} \mathrm{CaCl}_{2}, 0.6 \mathrm{~mm} \mathrm{MgCl}_{2}$ and $0.1 \%(\mathrm{w} / \mathrm{v}) \mathrm{NaN}_{3}\left(\mathrm{cHBSS}-\mathrm{NaN}_{3}\right)$. Serial dilutions of protein $\mathrm{C}(12.5-1000 \mathrm{nM})$ were prepared in cHBSS-NaN (ensuring a final concentration of $3 \mathrm{mM} \mathrm{CaCl}_{2}$ and $0.6 \mathrm{~mm}$ $\mathrm{MgCl}_{2}$ ) and added to the wells. Activation was initiated by the addition of purified human thrombin (ERL) (13.5 nM final concentration) to each well and was allowed to proceed for $30 \mathrm{~min}$ at $37{ }^{\circ} \mathrm{C}$ with gentle shaking. The reaction was terminated by the addition of hirudin (Sigma) (135 nM final concentration). Fifty microlitres of the resulting supernatant was incubated with $50 \mu \mathrm{L}$ of $2 \mathrm{~mm} \mathrm{~S}-2236$ chromogenic substrate and the initial rate of increase in absorbance at $405 \mathrm{~nm}$ was determined using an iEMS plate reader MF. Generated APC was estimated using a standard curve of purified APC. Curve fitting of the data to the Michaelis-Menten equation was performed using ENZFITTER software.

For activation of protein $\mathrm{C}$ on cells expressing thrombomodulin only, a similar assay was used, except that HEK293 cells stably transfected with full-length thrombomodulin (HEK293-TM) were used. Briefly, HEK293-TM cells were plated on a poly(L-lysine) (Sigma) coated 96-well plate, and grown to confluence over a $24-\mathrm{h}$ period. The cells were washed gently, and protein C (25-3000 nM) in cHBSS $-\mathrm{NaN}_{3}$ was added to the wells. Thrombin (13.5 nM final concentration) was added to each well, and the plate was then incubated for $30 \mathrm{~min}$ at $37{ }^{\circ} \mathrm{C}$ with gentle shaking. The reaction was stopped with hirudin (135 nM final concentration). Generation of APC was assessed using the chromogenic substrate S-2366 as above.

\section{Assessment of protein C-sEPCR interaction by surface plasmon resonance (SPR)}

All binding experiments were assessed by SPR using a dual flowcell BIAcore ${ }^{\circledR} \mathrm{X}$ biosensor system (BIAcore, AB, Uppsala, Sweden). To determine the concentration of sEPCR, an anti-EPCR monoclonal antibody (RCR-2) was covalently immobilized on a carboxymethylated dextran (CM5) sensor chip (BIAcore) using amine coupling chemistry, according to the manufacturer's instructions. A single time point on the association phase of wild-type sEPCR binding in triplicate was used to generate a calibration curve for sEPCR binding, the linear range of which was between 12.5 and $200 \mathrm{ng} \cdot \mathrm{mL}^{-1}$.

To characterize sEPCR binding to RCR-2, immobilization was performed by injecting $200 \mathrm{ng}$ RCR-2 across the sensor chip surface at a flow rate of $5 \mu \mathrm{L} \cdot \mathrm{min}^{-1}$. A response in resonance units (RU) of between 1500 and 4000 was established. A nonreactive mouse $\mathrm{IgG}$ was immobilized on the reference flow cell and used to control for nonspecific binding. Wild-type and variant forms of sEPCR (7.0$115 \mathrm{nM}$ ) were prepared in $50 \mathrm{~mm}$ Hepes $\mathrm{pH} 7.4,150 \mathrm{~mm}$ $\mathrm{NaCl}$ (HBS-P, BIAcore) and sequentially injected over the RCR-2 surface at a flow rate of $20 \mu \mathrm{L} \cdot \mathrm{min}^{-1}$ with $5 \mathrm{~min}$ contact time. The sensor chip surface was regenerated with $10 \mathrm{~mm}$ glycine/ $\mathrm{HCl}, \mathrm{pH} 2.5$.

To investigate protein $\mathrm{C}$ binding to sEPCR, protein $\mathrm{C}$ and concentrated sEPCR samples were buffer-exchanged into HBS-P with $3 \mathrm{mM} \mathrm{CaCl}_{2}, 0.6 \mathrm{mM} \mathrm{MgCl}_{2}$ by gel filtration. RCR-2 (300 ng) was injected for $6 \mathrm{~min}$ across both flow cells of a CM5 chip, generating a response of 3000 6000 RU. sEPCR in HBS-P, containing $3 \mathrm{mM} \mathrm{CaCl}_{2}$ and $0.6 \mathrm{mM} \mathrm{MgCl}_{2}$, was injected and equilibrated at $10 \mu \mathrm{L} \cdot \mathrm{min}^{-1}$ across one flow cell surface only providing an approximately equal amount $(\approx 500 \mathrm{RU})$ of sEPCR bound to RCR-2 for each experiment. Protein $\mathrm{C}$ concentrations $(0-200 \mathrm{nM})$ were sequentially injected over both flow cells at a flow rate of $30 \mu \mathrm{L} \cdot \mathrm{min}^{-1}$ for $80 \mathrm{~s}$. The flow cell without sEPCR bound was used as a reference cell. Any influence of mass transport effects was discounted from results of binding and dissociation at different flow rates. A buffer with $50 \mathrm{~mm}$ Hepes $\mathrm{pH} 7.4,150 \mathrm{~mm} \mathrm{NaCl}, 3 \mathrm{~mm}$ EDTA (HBS-EP, BIAcore), was used to dissociate the protein $\mathrm{C}-\mathrm{sEPCR}$ complex. After each set of experiments, the RCR-2 surface was regenerated with $10 \mathrm{~mm}$ glycine/ $\mathrm{HCl} \mathrm{pH} 2.5$. 


\section{Kinetic analysis of protein C binding to sEPCR}

Data analysis was performed using the BIAEVALUATION software 3.0 (BIAcore). The association and dissociation phases of all sensograms were fitted globally. Kinetics of wild-type and variant forms of sEPCR binding to RCR-2 were determined using a 1:1 Langmuir binding model. Protein $\mathrm{C}$ binding to sEPCR was fitted to a $1: 1$ baseline drift linear model.

\section{Phospholipid vesicle preparation}

A phospholipid mixture containing dioleoyl-phosphatidylcholine and dioleoyl-phosphatidylserine $(90: 10$, v/v) in chloroform (Avanti Polar Lipids Inc, Alabaster, AL, USA) was prepared, and the chloroform evaporated under nitrogen vapour. The phospholipids were resuspended in ice-cold sterile water then mixed vigorously for $1 \mathrm{~h}$ with shaking at $4{ }^{\circ} \mathrm{C}$. Unilamellar phospholipid vesicles were prepared by extrusion. The resuspended vesicles were passed 19 times through a $0.1 \mu \mathrm{m}$ membrane, then a further 19 times through a $0.03 \mu \mathrm{m}$ membrane using an Avanti Mini-Extruder (Avanti Polar Lipids Inc).

\section{Determination of APC-mediated factor Va inactivation}

To determine FVa degradation by APC, $0.08 \mathrm{~nm}$ APC was incubated with $75 \mu \mathrm{M}$ of the above phospholipid vesicles and $4 \mathrm{~nm}$ FVa (Haematologic Technologies Inc, VT, USA) in $40 \mathrm{~mm}$ Tris $/ \mathrm{HCl}, 140 \mathrm{mM} \mathrm{NaCl}, 3 \mathrm{~mm} \mathrm{CaCl}_{2}$ and $0.3 \%(\mathrm{w} / \mathrm{v})$ BSA $(0.02 \mathrm{~nm}$ APC, $19 \mu \mathrm{M}$ phospholipids and $1 \mathrm{nM} \mathrm{FVa}$; final concentration). The mixture was incubated at $37{ }^{\circ} \mathrm{C}$, and $2 \mu \mathrm{L}$ aliquots removed and added to a prothrombinase mixture, consisting of $75 \mu \mathrm{M}$ phospholipids (phosphatidylcholine and phosphatidylserine; $90: 10$, $\mathrm{v} / \mathrm{v}$ ), $3 \mathrm{nM}$ factor $\mathrm{Xa}$ and $1.5 \mu \mathrm{M}$ prothrombin (Haematologic Technologies Inc) ( $25 \mu \mathrm{M}$ phospholipids, $1 \mathrm{nM}$ factor $\mathrm{Xa}$ and $0.5 \mu \mathrm{M}$ prothrombin; final concentration) at defined time points between 0 and $20 \mathrm{~min}$. Each reaction was stopped after three minutes using $3 \mu \mathrm{L}$ ice-cold $0.5 \mathrm{M}$ EDTA. One-hundred microlitres of the reaction mixture was then removed and incubated with $50 \mu \mathrm{L}$ of chromogenic substrate S-2238 to assess thrombin generation, as the rate of thrombin generation was proportional to FVa activity. Calculation of kinetic rate constants for cleavage at Arg506 and Arg306 of FVa by APC was achieved using a model described previously for this purpose [12].

\section{Acknowledgements}

We thank Dr Rachel Simmonds and Dr Daniela Tormene for their invaluable help in the early phase of the work presented in this manuscript. This work was supported by grants from the British Heart Foundation, Associazione per la Lotta alla Trombosi ('ALTRO') and the Swedish Research Council (\#07143).

\section{References}

1 Esmon CT (1992) The protein C anticoagulant pathway. Arterioscler Thromb 12, 135-145.

2 Simmonds RE \& Lane DA (1998) Regulation of Coagulation. In Thrombosis and Hemorrhage (Loscalzo J \& Schafer AI, eds). Williams and Watkins, Baltimore.

3 Stearns-Kurosawa DJ, Kurosawa S, Mollica JS, Ferrell GL \& Esmon CT (1996) The endothelial cell protein C receptor augments protein $\mathrm{C}$ activation by the thrombin-thrombomodulin complex. Proc Natl Acad Sci USA 93, 10212-10216.

4 Fukudome K, Ye X, Tsuneyoshi N, Tokunaga O, Sugawara K, Mizokami H \& Kimoto M (1998) Activation mechanism of anticoagulant protein $\mathrm{C}$ in large blood vessels involving the endothelial cell protein C receptor. J Exp Med 187, 1029-1035.

5 Xu J, Esmon NL \& Esmon CT (1999) Reconstitution of the human endothelial cell protein $\mathrm{C}$ receptor with thrombomodulin in phosphatidylcholine vesicles enhances protein C activation. J Biol Chem 274, 6704-6710.

6 Esmon CT, Ding W, Yasuhiro K, Gu JM, Ferrell G, Regan LM, Stearns-Kurosawa DJ, Kurosawa S, Mather T, Laszik Z \& Esmon NL (1997) The protein C pathway: new insights. Thromb Haemost 78, 70-74.

7 Fay PJ, Smudzin TM \& Walker FJ (1991) Activated protein C-catalyzed inactivation of human factor VIII and factor VIIIa. Identification of cleavage sites and correlation of proteolysis with cofactor activity. $\mathrm{J} \mathrm{Biol}$ Chem 266, 20139-20145.

8 Kisiel W, Canfield WM, Ericsson LH \& Davie EW (1977) Anticoagulant properties of bovine plasma protein $\mathrm{C}$ following activation by thrombin. Biochemistry 16, 5824-5831.

9 Walker FJ, Sexton PW \& Esmon CT (1979) The inhibition of blood coagulation by activated Protein $\mathrm{C}$ through the selective inactivation of activated Factor V. Biochim Biophys Acta 571, 333-342.

10 Kalafatis M, Rand MD \& Mann KG (1994) The mechanism of inactivation of human factor $\mathrm{V}$ and human factor Va by activated protein C. J Biol Chem 269, 31869-31880.

11 Kalafatis M, Bertina RM, Rand MD \& Mann KG (1995) Characterization of the molecular defect in factor VR506Q. J Biol Chem 270, 4053-4057.

12 Nicolaes GA, Tans G, Thomassen MC, Hemker HC, Pabinger I, Varadi K, Schwarz HP \& Rosing J (1995) Peptide bond cleavages and loss of functional activity during inactivation of factor Va and factor VaR506Q by activated protein C. J Biol Chem 270, 21158-21166. 
13 Kalafatis M \& Mann KG (1993) Role of the membrane in the inactivation of factor Va by activated protein $\mathrm{C}$. $J$ Biol Chem 268, 27246-27257.

14 Norstrom E, Thorelli E \& Dahlback B (2002) Functional characterization of recombinant FV Hong Kong and FV Cambridge. Blood 100, 524-530.

15 Riewald M, Petrovan RJ, Donner A, Mueller BM \& Ruf W (2002) Activation of endothelial cell protease activated receptor 1 by the protein $\mathrm{C}$ pathway. Science 296, 1880-1882.

16 Cheng T, Liu D, Griffin JH, Fernandez JA, Castellino F, Rosen ED, Fukudome K \& Zlokovic BV (2003) Activated protein $\mathrm{C}$ blocks p53-mediated apoptosis in ischemic human brain endothelium and is neuroprotective. Nat Med 9, 338-342.

17 Bangalore N, Drohan WN \& Orthner CL (1994) High affinity binding sites for activated protein $\mathrm{C}$ and protein $\mathrm{C}$ on cultured human umbilical vein endothelial cells. Independent of protein $\mathrm{S}$ and distinct from known ligands. Thromb Haemost 72, 465-474.

18 Fukudome K \& Esmon CT (1994) Identification, cloning, and regulation of a novel endothelial cell protein C/activated protein C receptor. J Biol Chem $\mathbf{2 6 9}$, 26486-26491.

19 Fukudome K, Kurosawa S, Stearns-Kurosawa DJ, He X, Rezaie AR \& Esmon CT (1996) The endothelial cell protein $\mathrm{C}$ receptor. Cell surface expression and direct ligand binding by the soluble receptor. J Biol Chem 271, 17491-17498.

20 Regan LM, Mollica JS, Rezaie AR \& Esmon CT (1997) The interaction between the endothelial cell protein $\mathrm{C}$ receptor and protein $\mathrm{C}$ is dictated by the gamma-carboxyglutamic acid domain of protein C. J Biol Chem 272, 26279-26284.

21 Freedman SJ, Blostein MD, Baleja JD, Jacobs M, Furie BC \& Furie B (1996) Identification of the phospholipid binding site in the vitamin $\mathrm{K}$-dependent blood coagulation protein factor IX. $J$ Biol Chem 271, $16227-$ 16236.

22 Freedman SJ, Furie BC, Furie B \& Baleja JD (1995) Structure of the calcium ion-bound gamma-carboxyglutamic acid-rich domain of factor IX. Biochemistry 34, 12126-12137.

23 Soriano-Garcia M, Park CH, Tulinsky A, Ravichandran KG \& Skrzypczak-Jankun E (1989) Structure of Ca2+ prothrombin fragment 1 including the conformation of the Gla domain. Biochemistry 28, 6805-6810.

24 Soriano-Garcia M, Padmanabhan K, de Vos AM \& Tulinsky A (1992) The Ca2+ ion and membrane binding structure of the Gla domain of Ca-prothrombin fragment 1. Biochemistry 31, 2554-2566.

25 Oganesyan V, Oganesyan N, Terzyan S, Qu D, Dauter Z, Esmon NL \& Esmon CT (2002) The crystal structure of the endothelial protein $\mathrm{C}$ receptor and a bound phospholipid. J Biol Chem 277, 24851-24854.
26 Falls LA, Furie BC, Jacobs M, Furie B \& Rigby AC (2001) The omega-loop region of the human prothrombin gamma-carboxyglutamic acid domain penetrates anionic phospholipid membranes. J Biol Chem 276, 23895-23902.

27 Huang M, Rigby AC, Morelli X, Grant MA, Huang G, Furie B, Seaton B \& Furie BC (2003) Structural basis of membrane binding by Gla domains of vitamin Kdependent proteins. Nat Struct Biol 10, 751-756.

28 Simmonds RE \& Lane DA (1999) Structural and functional implications of the intron/exon organization of the human endothelial cell protein $\mathrm{C} /$ activated protein $\mathrm{C}$ receptor (EPCR) gene: comparison with the structure of CD1/major histocompatibility complex alpha1 and alpha2 domains. Blood 94, 632-641.

29 Villoutreix BO, Blom AM \& Dahlback B (1999) Structural prediction and analysis of endothelial cell protein $\mathrm{C} /$ activated protein $\mathrm{C}$ receptor. Protein Eng 12, 833-840.

30 Fukudome K \& Esmon CT (1995) Molecular cloning and expression of murine and bovine endothelial cell protein $\mathrm{C} /$ activated protein $\mathrm{C}$ receptor (EPCR). The structural and functional conservation in human, bovine, and murine EPCR. J Biol Chem 270, 5571-5577.

31 Liaw PC, Mather T, Oganesyan N, Ferrell GL \& Esmon CT (2001) Identification of the protein C/activated protein $\mathrm{C}$ binding sites on the endothelial cell protein $\mathrm{C}$ receptor. Implications for a novel mode of ligand recognition by a major histocompatibility complex class 1-type receptor. $J$ Biol Chem 276, 8364-8370.

32 Reitsma PH, Bernardi F, Doig RG, Gandrille S, Greengard JS, Ireland H, Krawczak M, Lind B, Long GL, Poort SR et al. (1995) Protein C deficiency: a database of mutations, 1995 update. On behalf of the Subcommittee on Plasma Coagulation Inhibitors of the Scientific and Standardization Committee of the ISTH.

Thromb Haemost 73, 876-889.

33 Christiansen WT, Jalbert LR, Robertson RM, Jhingan A, Prorok M \& Castellino FJ (1995) Hydrophobic amino acid residues of human anticoagulation protein $\mathrm{C}$ that contribute to its functional binding to phospholipid vesicles. Biochemistry 34, 10376-10382.

34 Christiansen WT, Tulinsky A \& Castellino FJ (1994) Functions of individual gamma-carboxyglutamic acid (Gla) residues of human protein C. Determination of functionally nonessential Gla residues and correlations with their mode of binding to calcium. Biochemistry 33, 14993-15000.

35 Jalbert LR, Chan JC, Christiansen WT \& Castellino FJ (1996) The hydrophobic nature of residue-5 of human protein $\mathrm{C}$ is a major determinant of its functional interactions with acidic phospholipid vesicles. Biochemistry 35, 7093-7099.

36 Shen L, Shah AM, Dahlback B \& Nelsestuen GL (1997) Enhancing the activity of protein C by 
mutagenesis to improve the membrane-binding site: studies related to proline-10. Biochemistry 36, 1602516031.

37 Sun YH, Shen L \& Dahlback B (2003) Gla domainmutated human protein $\mathrm{C}$ exhibiting enhanced anticoagulant activity and increased phospholipid binding. Blood 101, 2277-2284.

38 Zhang L \& Castellino FJ (1993) The contributions of individual gamma-carboxyglutamic acid residues in the calcium-dependent binding of recombinant human protein $\mathrm{C}$ to acidic phospholipid vesicles. $\mathrm{J}$ Biol Chem 268, 12040-12045.

39 Nelsestuen GL (1999) Enhancement of vitamin-Kdependent protein function by modification of the gamma-carboxyglutamic acid domain: studies of protein C and factor VII. Trends Cardiovasc Med 9, 162-167.

40 Regan LM, Stearns-Kurosawa DJ, Kurosawa S, Mollica J, Fukudome K \& Esmon CT (1996) The endothelial cell protein $\mathrm{C}$ receptor. Inhibition of activated protein $\mathrm{C}$ anticoagulant function without modulation of reaction with proteinase inhibitors. $J$ Biol Chem 271, 17499-17503.

41 Shen L, Villoutreix BO \& Dahlback B (1999) Involvement of Lys 62 (217) and Lys 63 (218) of human anticoagulant protein $\mathrm{C}$ in heparin stimulation of inhibition by the protein C inhibitor. Thromb Haemost 82, 72-79.

42 Shen L, Villoutreix BO \& Dahlback B (1999) Interspecies loop grafting in the protease domain of human protein $\mathrm{C}$ yielding enhanced catalytic and anticoagulant activity. Thromb Haemost 82, 1078-1087.

43 Sala N, Owen WG \& Collen D (1984) A functional assay of protein $\mathrm{C}$ in human plasma. Blood 63, 671-675.

44 Norstrom EA, Steen M, Tran S \& Dahlback B (2003) Importance of protein $\mathrm{S}$ and phospholipid for activated protein C-mediated cleavages in factor Va. $J$ Biol Chem 278, 24904-24911.

45 Wojcik EG, Simioni P, de Berg M, Girolami A \& Bertina RM (1996) Mutations which introduce free cysteine residues in the Gla-domain of vitamin $\mathrm{K}$ dependent proteins result in the formation of complexes with alpha 1-microglobulin. Thromb Haemost 75, 70-75.

46 Ido M, Ohiwa M, Hayashi T, Nishioka J, Hatada T, Watanabe Y, Wada H, Shirakawa S \& Suzuki K (1993) A compound heterozygous protein $\mathrm{C}$ deficiency with a single nucleotide $\mathrm{G}$ deletion encoding Gly-381 and an amino acid substitution of Lys for Gla-26. Thromb Haemost 70, 636-641.

47 Nishioka J, Ido M, Hayashi T \& Suzuki K (1996) The Gla26 residue of protein $\mathrm{C}$ is required for the binding of protein $\mathrm{C}$ to thrombomodulin and endothelial cell protein $\mathrm{C}$ receptor, but not to protein $\mathrm{S}$ and factor $\mathrm{Va}$. Thromb Haemost 75, 275-282.

48 Stearns-Kurosawa DJ, Mather T, Kurosawa S \& Esmon CT (1999) The binding site on protein $C$ for the endothelial cell protein C receptor. Blood 94, 2878.
49 McDonald JF, Shah AM, Schwalbe RA, Kisiel W, Dahlback B \& Nelsestuen GL (1997) Comparison of naturally occurring vitamin K-dependent proteins: correlation of amino acid sequences and membrane binding properties suggests a membrane contact site. Biochemistry 36, 5120-5127.

50 Faioni EM, Hermida J, Rovida E, Razzari C, Asti D, Zeinali S \& Mannucci PM (2000) Type II protein C deficiency: identification and molecular modelling of two natural mutants with low anticoagulant and normal amidolytic activity. Br J Haematol 108, 265-271.

51 Marshall JC (2003) Such stuff as dreams are made on: mediator-directed therapy in sepsis. Nat Rev Drug Discov 2, 391-405.

52 Domotor E, Benzakour O, Griffin JH, Yule D, Fukudome K \& Zlokovic BV (2003) Activated protein C alters cytosolic calcium flux in human brain endothelium via binding to endothelial protein $\mathrm{C}$ receptor and activation of protease activated receptor-1. Blood 101, 4797-4801.

53 Hermida J, Hurtado V, Villegas-Mendez A, Catto AJ \& Philippou H (2003) Identification and characterization of a natural R96C EPCR variant. $J$ Thromb Haemost 1, 1850-1852.

54 Simioni P, Kalafatis M, Tormene D, Luni S, Zerbinati P, Barzon L, Palu G \& Girolami A (2001) Abnormal propeptide processing resulting in the presence of two abnormal species of protein $\mathrm{C}$ in plasma: characterization of the dysfunctional protein $\mathrm{C}$ Padua3 (protein $\mathrm{C}$ (R-1L/propeptide). Thromb Haemost 86, 1017-1022.

55 Rezende SM, Lane DA, Zoller B, Mille-Baker B, Laffan M, Dahlback B \& Simmonds RE (2002) Genetic and phenotypic variability between families with hereditary protein S deficiency. Thromb Haemost 87, 258-265.

56 Zhang L \& Castellino FJ (1990) A gamma-carboxyglutamic acid (gamma) variant (gamma 6D, gamma 7D) of human activated protein $\mathrm{C}$ displays greatly reduced activity as an anticoagulant. Biochemistry 29, 1082810834.

57 Yang L, Manithody C \& Rezaie AR (2002) Contribution of basic residues of the 70-80-loop to heparin binding and anticoagulant function of activated protein $\mathrm{C}$. Biochemistry 41, 6149-6157.

58 Edgell CJ, McDonald CC \& Graham JB (1983) Permanent cell line expressing human factor VIII-related antigen established by hybridization. Proc Natl Acad Sci USA 80, 3734-3737.

59 Suzuki K, Kusumoto H, Deyashiki Y, Nishioka J, Maruyama I, Zushi M, Kawahara S, Honda G, Yamamoto S \& Horiguchi S (1987) Structure and expression of human thrombomodulin, a thrombin receptor on endothelium acting as a cofactor for protein $\mathrm{C}$ activation. EMBO J 6, 1891-1897. 